\title{
In Vivo Antioxidant And Kidney Protective Potential Of Atorvastatin In Rat Cadmium-Induced Toxicity
}

\section{Esmaeil Karami}

Tehran University of Medical Sciences

\section{Zahra Goodarzi}

Semnan University of Medical Sciences and Health Services

\section{Ali Ghanbari}

Pasteur Institute of Iran

\section{Ahmad Reza Bandegi}

Pasteur Institute of Iran

\section{Sedighe Yosefi}

Semnan University of Medical Sciences and Health Services

Alireza Dehdashti ( $\boldsymbol{\nabla}$ dehdashti@semums.ac.ir)

Semnan University of Medical Sciences and Health Services https://orcid.org/0000-0001-7361-2524

\section{Research Article}

Keywords: Atorvastatin, cadmium chloride, kidney, rat model, treatment, oxidative stress

Posted Date: June 15th, 2021

DOI: https://doi.org/10.21203/rs.3.rs-589839/v1

License: (c) (i) This work is licensed under a Creative Commons Attribution 4.0 International License. Read Full License 


\section{Abstract}

Purpose: Environmental and occupational exposure to cadmium chloride is known to cause nephrotoxicity linked with oxidative stress in humans and animals. This study used Atorvastatin to examine its effect on cadmium chloride-induced nephrotoxicity in rat model using biochemical and histological methodologies.

Methods: Experiments were performed on 56 adult male Wistar rats $(200 \pm 20 \mathrm{~g})$, randomly assigned to eight groups. Atorvastatin was administered by oral for 15 days at $20 \mathrm{mg} / \mathrm{kg} /$ day, started 7 days before cadmium chloride intraperitoneal administration $(1,2$, and $3 \mathrm{mg} / \mathrm{kg})$ for eight days. On day 16 , blood samples were collected, and kidneys were excised to evaluate the biochemical and histopathological changes.Cadmium chloride significantly increased malondialdehyde (MDA), serum creatinine (Cr), blood urea nitrogen (BUN), and decreased superoxide dismutase (SOD), glutathione (GSH), and glutathione peroxidase (GPx) levels.

Results: Administration of Atorvastatin $(20 \mathrm{mg} / \mathrm{kg}$ ) significantly improved lipid peroxidation, glutathione and activities of antioxidant enzymes and significantly decreased BUN and Creatinine. Atorvastatin clearly improved the histological changes, demonstrating its protective role against Cadmium chlorideinduced kidney injury.

Conclusion: Treatment with Atorvastatin significantly improves all biochemical parameters and suggests a protecting role against cadmium chloride-induced oxidative stress and histological changes in rat kidney.

\section{Introduction}

Cadmium (Cd) is frequently used in various industrial processes and considered as one of toxic metals to environment. Occupational and environmental exposures to $\mathrm{Cd}$ are linked to industrial activities. (Mezynska and Brzóska, 2018) The kidney is known as the main target organ for chronic Cd exposure. (Rana et al., 2018) The biological half-life of $\mathrm{Cd}$ in humans reported 10 to 30 years in the kidney cortex which may account for a higher occurrence of nephrotoxicity.(Moitra et al., 2014) In the kidney, the accumulation of $50 \mu \mathrm{g} \mathrm{Cd} / \mathrm{g}$, wet tissue weight resulted in renal dysfunction (Satarug et al., 2000).

Evidence suggests that $\mathrm{Cd}$ absorption may result in oxidative stress. Cd-induced oxidative injury includes a difference between production and removal of reactive oxygen species (ROS) in kidney. Furthermore, the production and accumulation of ROS are associated with hydrogen peroxide (H2O2), hydroxyl radical $(\mathrm{OH}-)$, superoxide anions, singlet oxygen, lipid hydroperoxides and phospholipid hydroperoxides,(Patra et al., 2011) causing inflammation and injury in cell membrane, enzymatic pathways, and connective tissue structures.(Gabr et al., 2019) Cd-induced nephrotoxicity may be related to toxic intermediates generated in the kidney.(Talebpour Amiri et al., 2018) Moreover, decrease in antioxidant activity may have a pathological role in biological reactions and Cd-induced nephrotoxicity.(Şişman et al., 2003) Cd is filtered 
by the glomeruli and is then reabsorbed by the epithelial cells of the proximal tubule, possessing a potent toxic effect on the kidney.(Rana et al., 2018; Yang and Shu, 2015)

Cd is known to cause physiological and biochemical effects in animals and humans.(Bernhoft, 2013; Patra et al., 2011; Renugadevi and Prabu, 2009) Cd administration in rats resulted in significant decrease of antioxidant indicators such as superoxide dismutase (SOD), glutathione peroxidase (GPX), catalase (CAT), and glutathione (GSH), and a rise in malondialdehyde (MDA) peroxidation marker in kidney. (Andjelkovic et al., 2019; Evcimen et al., 2020; Hormozi et al., 2018; Kim et al., 2018) Chronic exposure to Cd may attribute to some morphological and metabolic alterations, causing an increased dose-dependent in blood urea nitrogen (BUN) and Creatinine in rats.(Renugadevi and Prabu, 2009) Meanwhile, Long-term Cd exposure can develop tissue necrosis in rats.(Erboga et al., 2016; Kim et al., 2018)

Atorvastatin (AT) is the leading antioxidant of the class of statins and has been shown to possess antiinflammatory, antioxidant (10 mg/kg, for 10 days),(Pal et al., 2015) antithrombotic (10 mg/kg/day), (Ozbek et al., 2009) antiplatelet, immunomodulatory (40 mg for 4 weeks),(Fuentes-Orozco et al., 2018) and antitumor effects in experimental animal models.(Garjani et al., 2012) Doses of Statin compounds at $20 \mathrm{mg} /$ day have reduced inflammation by HMG-CoA reductase inhibitors, lowered low-density lipoprotein (LDL) cholesterol in plasma, and promoted antioxidant effects by suppressing oxidation pathways.

(Goodarzi et al., 2016; Wang et al., 2017) AT is a potent HMG-CoA reductase inhibitor and effective in lipid profiles, lipid peroxidation, and antioxidant systems.(Yan et al., 2020) It has been reported that Atorvastatin ameliorated renal dysfunction,(El-Moselhy and El-Sheikh, 2014) morphological changes,(Yan et al., 2020) and oxidative stress injuries in rats.(Wu et al., 2014)

Overall, the widespread emission of $\mathrm{Cd}$ has increased exposure in working and general population and demanded further research to prevent health-related hazards. However, few experimental studies have investigated and reported the protective role of atorvastatin on toxic metals in animal model with renal failure. As per our knowledge, the protective role of AT on Cadmium-induced nephrotoxicity in rats has not been demonstrated. Therefore, the main goal of the current experiment was to investigate in vivo biochemical and histological changes induced by $\mathrm{CdCl} 2$ on the kidney of adult rat model. We evaluated the possible role of Atorvastatin in protecting $\mathrm{CdCl}$-induced renal toxicity in rats and in ameliorating the renal oxidative stress biomarkers and histological changes in rats.

\section{Materials And Methods}

\subsection{Experimental Animals}

Adult Wistar male rats $(n=56)$ weighing between 200 and $220 \mathrm{~g}$ were used. The animals were housed in metal cages ( 7 rats in each cage) under hygienic conditions and maintained at $22 \pm 2^{\circ} \mathrm{C}$ and 12 -hour lightdark cycles with free access to food and water. Rats were acclimatized for one week before treatment commenced.

\subsection{Ethics}


Prior to the experiment, we reviewed and ensured that the protocols were in accordance with the guidelines of animal acts proposed by the institutional Ethical Review Board of Semnan University of Medical Sciences (IR.SEMUMS.REC.1395.177).

\subsection{Drug and Chemicals}

AT was purchased from Tehran Chemie pharmaceutical Co. Cadmium chloride ( $\mathrm{CdCl} 2)$ was obtained from Merck (Darmstadt, Germany). Biochemical markers were assessed using Rat SOD, GPx, MDA, GSH ELISA Kits from ZellBio, GmbH, (Gerrmany) as instructed by manufacturer. BUN and Creatinine in the kidney tissues were detected as instructed by kits obtained from Pars Azmun Pharmaceutical (Iran). Purchased Chemicals were of standard grade and purity for performing experimental tests.

\subsection{Rat treatments}

Rats pretreated with AT (20-mg/kg),(Goodarzi et al., 2020; Sun et al., 2009) dissolved in saline solution and gastric gavage at a dose of $4 \mathrm{ml} / \mathrm{kg}$. Doses of $\mathrm{Cdcl} 2$ (1, 2, and $3 \mathrm{mg} / \mathrm{kg})$,(Golbaghi et al., 2019) was dissolved in distilled water and was administered at a dose of 2-ml/kg intraperitoneally. Cd or its vehicle (normal saline) was used 30 minutes after gavage administration of AT or its vehicle. Rats were treated with intra-gastric gavage of saline, AT, or vehicle of AT for 15 days, which started 7 days before intraperitoneal injection of cadmium chloride or its vehicle. On day 16 samples were taken for biochemical and histological analyses. Period of experimental treatments is shown in Fig. 1.

\subsection{Experimental groups}

The wistar rats were randomly assigned into eight groups of seven rats in each group. The first group of rats received physiologic saline. The second group treated with oral gavages a dose of $20 \mathrm{mg} / \mathrm{kg} / \mathrm{day}$ AT for 15 days. The third, fifth, and seventh groups received intraperitoneal (i.p.) $\mathrm{CdCl} 2$ with doses of 1, 2 and $3 \mathrm{mg} / \mathrm{kg}$, while the fourth, sixth, and eighth groups pretreated with oral gavages containing $20 \mathrm{mg}$ AT/kg body weight, 30 minutes prior to the intraperitoneal (i.p.) administration of $\mathrm{CdCl} 2$ at 1, 2 and 3 $\mathrm{mg} / \mathrm{kg}$. All animals received $\mathrm{Cdcl} 2$ from day 8 to day 15. After 24 hours of the last administration blood samples were taken from the heart under anesthesia with sodium pentobarbital (50 mg/kg). Excised Kidneys were washed thoroughly with saline solution. Obtained parts of kidney tissues were fixed and examined by light microscopy, using hematoxylin and eosin (H\&E) staining technique and a $0.5 \cdot 0.5-\mathrm{cm}^{2}$ slices of additional half was cut for the measurement of GSH, SOD, MDA and GPX.

\subsection{Histological analyses}

Renal tissues were fixed in buffered formalin (10\%) for 48 hours and embedded in paraffin wax. Slices of $10 \mu \mathrm{m}$ were cut and placed on glass slides. After making and drying kidney tissue slides, they were stained with hematoxylin and eosin (H\&E) method. Kidney cell injury was examined based on dilated nuclei, loss of staining capacity and swelling of kidney tubular cells. Five fields of each slide were randomly selected and photographed under a magnification of $x 400$ and evaluated by a pathologist and a histologist. 


\subsection{Biochemical analyses}

The samples of kidney tissue were washed and homogenized with phosphate buffered saline. The supernatants were prepared by centrifuging the homogenates at $800 \times \mathrm{g}$ for $10 \mathrm{~min}$ at $4^{\circ} \mathrm{C}$, and preserved the samples in $-80^{\circ} \mathrm{C}$. The activities of GSH, MDA, GPx, and SOD were measured in the obtained supernatants,(Yang and Shu, 2015) Serum was separated from blood samples by centrifugation at 3000 rpm for 20 minutes and stored at $-20^{\circ} \mathrm{C}$ until the measurement of parameters. Serum levels of BUN, CR and the renal tissues levels of GSH, MDA, GPx, and SOD were measured as instructed by relevant kits. Serum level of BUN was assayed using colorimetric kit according to the method described. Serum level of Cr was measured by Jaffe's method.(Brouwers et al., 2013) The Concentrations of GSH, MDA, GPx, and SOD in kidney tissues were measured as per the instructions of kits from ZellBio GmbH (Ulm, Germany).

Thiobarbituric acid reaction with MDA Assay kit estimated the level of lipid peroxidation. Adding thiobarbituric acid to MDA results in the formation of red complex product that was measured at $532 \mathrm{~nm}$ by a NanoDrope Spectrophotometer.. The detection limit of MDA was $0.1 \mu \mathrm{M}$.(Pirmoradi et al., 2019) An assay kit (Zellbio Co) was used to measure the activity of SOD in kidney tissue. Measurement of SOD was based on an enzyme reacting with superoxide anion to produce oxygen and hydrogen peroxide. GSH and GPx were quantified by colorimetric method at $412 \mathrm{~nm}$, using chemical assay kits ZellBio $\mathrm{GmbH}$, (Ulm, Germany) with a $0.1 \mathrm{mM}$ detection limit.(Sheikh, 2016) The content of renal Gpx was assessed by measuring NADH catalyzed one micromole GSH per minute to Oxidized glutathione (GSSG). The protein content of supernatant was assayed according to method described by Bradford method using standard bovine serum albumin at $560 \mathrm{~nm}$.(Verdi et al., 2005)

\subsection{Statistical analyses}

Statistical analyses were performed using the Graphpad Prism 8 software. Experimental data were processed to present the Standard Error Means. Data were analyzed by one-way analysis of variance (ANOVA), and Tukey's multiple comparisons tests were performed to compare the means of all groups to the mean of every other group. Differences were statistically considered significant at $\mathrm{P}<0.05$.

\section{Results}

\section{3 - 1. Effects of Cd and Atorvastatin on kidney MDA level}

MDA level in the rat kidney homogenates increased significantly in the group treated with $\mathrm{CdCl} 2$ compared to control group ( $\mathrm{Cd} 3 \mathrm{mg} / \mathrm{kg} / \mathrm{day}$, ${ }^{\star} \mathrm{P}=.0011$ and $\left.\mathrm{Cd} 2 \mathrm{mg} / \mathrm{kg} / \mathrm{day}{ }^{*} \mathrm{P}=0.0428\right)$. Atorvastatin at dose of $20 \mathrm{mg} / \mathrm{kg} /$ day significantly decreased MDA level in CdCl 2 treated rats (Cd $3 \mathrm{mg} / \mathrm{kg} / \mathrm{day}+\mathrm{AT}$ $20 \mathrm{mg} / \mathrm{kg} /$ day, ${ }^{*} \mathrm{P}=0.0268$ ) as illustrated in Fig. 2.

The activities of non-enzymatic antioxidants (GSH) and, enzymatic (SOD and GPx) in the kidney of rats are shown in Figures 3-a, 3-b, and 3-c. 
The effect of $\mathrm{Cdcl} 2$ on GSH levels and treatment with a combination of $\mathrm{CdCl} 2$ plus AT on GSH concentration of rat renal tissues is depicted in Fig. 3-a. The administration of Cdcl2 significantly decreased GSH concentration compared to control values in kidney ( $\mathrm{Cd} 3 \mathrm{mg} / \mathrm{kg} / \mathrm{day}$, $\left.{ }^{\star \star} \mathrm{P}=.0078\right)$. The combination of $\mathrm{Cdcl} 2$ with AT significantly altered kidney GSH content compared to $\mathrm{CdCl} 2$ treated rats (Cd $2 \mathrm{mg} / \mathrm{kg} / \mathrm{day}+$ AT 20mg/kg/day, *P .0401 and Cd $3 \mathrm{mg} / \mathrm{kg} /$ day + AT $20 \mathrm{mg} / \mathrm{kg} /$ day, ${ }^{*} \mathrm{P}=.0390$ ).

\subsubsection{Superoxide dismutase (SOD)}

In rats given Cdcl2 at a dose of $3 \mathrm{mg} / \mathrm{kg}$, SOD activity significantly lowered compared to control group (**P $=0.0056)$. Equally, pretreatment of AT $(20 \mathrm{mg} / \mathrm{kg} / \mathrm{day})$ significantly increased SOD enzymatic activity ( $\left.{ }^{\mathrm{P}}=0.0323\right)$ compared to $\mathrm{Cdcl} 2$-treated group $(1 \mathrm{mg} / \mathrm{kg} /$ day) as depicted in Fig. 3-b.

The effect of Cdcl2 on rat kidney tissues GPx activity and treatment with a combination of Cdcl2 plus AT on the rat tissue GPx activity is depicted in Fig. 3-c. Administration of $\mathrm{Cdcl} 2$ significantly reduced GPx concentration in kidney compared to control values $\left(\mathrm{Cd} 2 \mathrm{mg} / \mathrm{kg} /\right.$ day, ${ }^{*} \mathrm{P}=0.0138$ and $\mathrm{Cd} 3 \mathrm{mg} / \mathrm{kg} / \mathrm{day}$, $\star * \mathrm{P}<0.0078)$. The combination of Cdcl2 plus AT increased kidney GPx content compared to $\mathrm{CdCl} 2$ treated rats, but the difference was not significant.

\section{3-3. Effects of treatments on the serum level of BUN}

A dose of $3-\mathrm{mg} / \mathrm{kg}$ Cdcl2 significantly increased BUN compared to the rats treated with saline $(* * P<0.01)$ but not significantly at dose of $2 \mathrm{mg}$ as shown in Fig. 4. Pretreatment with AT ( $20 \mathrm{mg} / \mathrm{kg} / \mathrm{day})$ significantly decreased BUN level in Cd-induced changes of 1 and $3 \mathrm{mg} / \mathrm{kg}\left({ }^{*} \mathrm{P}<0.05\right)$ and control group $(* \star * P<0.01)$ but not significantly at $\mathrm{Cd}$ dose of $2 \mathrm{mg} / \mathrm{kg}$.

\section{3-4. Effects of $\mathrm{Cdcl}_{2}$ and AT on the serum level of Creatinine}

Figure 5 shows the status of creatinine serum level of control group and experimental group. $\mathrm{CdCl} 2$ administration ( $3 \mathrm{mg} / \mathrm{kg} /$ day) significantly increased creatinine in the serum as compared to control rats $(\star \star P=0.0029)$. Increased levels of creatinine due to $\mathrm{CdCl} 2$ challenge were significantly decreased at doses of 1,2 , and $3 \mathrm{mg} / \mathrm{kg} /$ day upon the pre-treatment with Atorvastatin $20 \mathrm{mg} / \mathrm{kg} / \mathrm{day}(\mathrm{Cd} 1+\mathrm{AT} * \star \mathrm{P}=$ $0.0072, C d 2+A T * * P=0.0048, C d 3+A T * P=.0155)$.

\section{3-5. Histological changes in the rat kidney:}

The Histological examination on the renal tissues of the control rats demonstrated normal architecture and regularly arranged kidney tissue cells in both lateral cortex and medullary segments, respectively. In the central part of the tissue, normal epithelial cells were arranged in the collecting duct. The appearance of epithelial cells and glomerular size were observed normal in the proximal convoluted tubule and the distal convoluted tubule (Fig. 6-a).

The kidney tissue of $\mathrm{CdCl} 2$-treated rats group demonstrated severe histological damages, where renal glomerular size was reduced compared to normal tissue and hemorrhage was observed inside the 
Bowman's capsule. Lymphocytic cells increased in the renal tissues and the death of epithelial cells in the wall of Bowman's capsule was observed in glomeruli. Disrupted epithelial cells were deposited in the collector duct. In the central part of the tissue, the number of renal cells in the proximal and distal convoluted tubules was indistinguishable, indicating histopathological alterations in the cellular structure. Further, in rats treated with $\mathrm{Cdcl} 2$, the aggregation of interstitial lymphocyte infiltration was increased in renal tubular cells, and vacuolated cytoplasm was observed, which ultimately led to cellular death (Fig. 6-b). In the central part of the tissue, abnormal epithelial cells were placed in the collection duct.

In contrast, these histopathological changes were reduced in the kidney of rats following administration of $\mathrm{CdCl} 2$ and AT $(20 \mathrm{mg} / \mathrm{kg} /$ day). The results of this study in the rat groups treated with $\mathrm{CdCl} 2$ and AT 20 $\mathrm{mg} / \mathrm{kg} /$ day showed that Bowman's capsule wall epithelial cells in the kidney glomeruli had a normal appearance. Bowman space is slightly larger in the distance between the epithelial cells and the vessel wall thicker than in the control groups. The percentage of lymphocyte cells in tissue was normal and interstitial hemorrhage was not observed. In the cortical tissue, the entire complex tubes were seen around and near the epithelial wall and the cells were aligned. The epithelial cells near the convoluted tubules and the surrounding tubules were normal (Fig. 6-C).

\section{Discussion}

This in-vivo experimental study examined the potential effects of AT on Cdcl2-induced kidney toxicity in rat. Our results showed that administration of Cdcl2 significantly increased MDA levels, and decreased the enzymatic and non-enzymatic antioxidants in the kidney of rats. Similarly, Renugadevi et al. (Renugadevi and Prabu, 2009) suggested oxidative stress as the main mechanism of acute Cd toxicity. Prior studies reported significant increased MDA levels in the kidney from $\mathrm{CdCl} 2$-administered rats.(Gabr et al., 2019; Mohammed and Hashem, 2019) In addition, Mohammed et al.(Mohammed and Hashem, 2019) reported that $\mathrm{CdCl} 2$ ( $5 \mathrm{mg} / \mathrm{kg} /$ day) orally for 30 days significantly increased MDA, lowered activity of GSH and histopathological changes in the rat. Our results suggest that $\mathrm{CdCl} 2$ administration resulted in the reduction of renal GSH concentration as compared to control group, which is in agreement with the previous results obtained by Xiao,(Xiao et al., 2002) and Messaoudi et al.(Messaoudi et al., 2009) Indeed, these findings agreed with previous study on cadmium in male jewelry manufacturing workers, indicated decrease in plasma antioxidant enzymes, and increase in MDA and erythrocyte instability.(Moitra et al., 2014)

Our results showed the administration of $\mathrm{CdCl} 2$ significantly decreased GPx (doses of 2 and $3 \mathrm{mg} / \mathrm{kg}$ ), SOD, and GSH (dose of $3 \mathrm{mg} / \mathrm{kg}$ ) activities in the kidney compared to a control group and resulted in oxidative stress in the rat kidney that was reflected by the renal histopathological and biochemical changes. Our results were in agreement with a rat experimental study by Adi et al.(Adi et al., 2016) concluded that $\mathrm{Cd}$ exposure ( $20 \mathrm{mg} / \mathrm{kg}$ bodyweight for 30 days) meaningfully reduced CAT, GR, SOD, and GPx activities and improved LPx and GST activities. Also, Hormozi et al.(Hormozi et al., 2018) demonstrated that concurrent workplace exposure to lead and cadmium in tile industry might result in a 
remarkable increase in lipid peroxidation, and altered antioxidant enzymes (CAT, SOD, and GPx) and oxidative stress.

In our study, the functional nephrotoxicity was indexed through BUN and creatinine levels, which were increased in $\mathrm{CdCl} 2$-treated rats as matched to control rats. Our results confirm the study by Wallin et al. (Wallin et al., 2014) revealed a link between Cd levels in urine and blood with exposure to $\mathrm{Cd}$ and chronic kidney disease. Our findings also correlated with the results of Andjelkovic et al.(Andjelkovic et al., 2019) that suggested Cd (15 and $30 \mathrm{mg} / \mathrm{kg}$ BW) significantly increased BUN and Cr compared to a control group Cdcl2-induced oxidative stress in rat kidney. Another study showed that BUN and serum creatinine levels significantly reduced following administration of $\mathrm{CdCl} 2(25 \mathrm{mg} / \mathrm{kg}$, orally for 7 days) in rat.(Kim et al., 2018) Previous studies have shown severe histological changes in the kidney of $\mathrm{CdCl} 2$-treated rats. (Gabr et al., 2019; Mohammed and Hashem, 2019) Besides, CdCl2 exposure induced toxic injuries to the renal and declined glomerular function and progressive renal failure in the kidney, as seen by histopathological examination of the current study and as reported before by Gabr,(Gabr et al., 2019) Renugadevi,(Renugadevi and Prabu, 2009) and Mohammed et al.(Mohammed and Hashem, 2019)

Our experiment revealed that the pretreatment of AT before $\mathrm{CdCl} 2$ poisoning improved biochemical parameters. Previous study showed protective effect of AT on antioxidant enzymes and inhibits the reduction of endogenous antioxidant enzymes.(Ozbek et al., 2009) In this study, taking AT (20 $\mathrm{mg} / \mathrm{kg} /$ day) plus $\mathrm{CdCl} 2$ did have much biochemical and pathological impact in rat kidney. However, conflicting results have been reported regarding the effect of AT on renal tissue. Some studies find the effect toxic and others find it useful and supportive.(Mehrzadi et al., 2016; Nasri et al., 2016) Mehany et al.(Mehany et al., 2013) reported the effect of pretreatment with AT and vitamin E on rat's kidney. They suggested that in potassium dichromate-induced nephrotoxicity $(15 \mathrm{mg} / \mathrm{kg})$ in rat, pretreatment with vitamin $\mathrm{E}(200 \mathrm{mg} / \mathrm{k})$ and Atorvastatin $(10 \mathrm{mg} / \mathrm{kg} /$ day for 14 days) resulted in lowered toxicity and as well as improvement of kidney histopathological changes. In another study, Talebpour et al.(Talebpour Amiri et al., 2018) reported that AT administration produced a significant protective effect against radiation-induced nephrotoxicity.

A study reported opposite results showed that administration of AT ( $30 \mathrm{mg} / \mathrm{kg} / \mathrm{day}$ for 8 weeks) induced adverse effect in renal tissues and a post-treatment of Arjunolic acid $(20 \mathrm{mg} / \mathrm{kg}$ for 4 days) and vitamin $\mathrm{C}$ might protect kidney from AT-induced severe tissue toxicity.(Pal et al., 2015) Three major differences between our findings and the results of Pal et al.(Pal et al., 2015) could be due to the discrepancy between dose, exposure time, and animals. In the current study, rats were exposed to $20 \mathrm{mg} / \mathrm{kg}$ AT for 15 days, while in Pal et al.(Pal et al., 2015) study mice were given $30 \mathrm{mg} / \mathrm{kg} /$ day AT for 8 weeks.

Our results highlighted that the administration of $\mathrm{CdCl} 2$ in rat model may lead to nephrotoxicity. Histological examination showed many alterations in renal tissue structure following exposure to $\mathrm{CdCl} 2$ (Fig. 6b). These results consistent with those of Mohammad et al.(Mohammed and Hashem, 2019) which described $\mathrm{CdCl} 2$ ( $5 \mathrm{mg} / \mathrm{kg}$ b.w, orally for 4 weeks) induced glomerular injury, acute dilatation of Bauman's capsule, congestion of the renal blood vessels, and injury to glomerular epithelial in rat. 
A previous report concluded that $\mathrm{CdCl} 2$ administration ( $5 \mathrm{mg} / \mathrm{kg}$ for 30 days) indicated adverse effect on cortical blood flow and renal parenchyma replacement with numerous lymphocytes infiltrates, and dilation of glomeruli in rat.(Gabr et al., 2019) Also, El-Sokkary et al.(El-Sokkary et al., 2010) who reported that $\mathrm{CdCl} 2$ (5-mg / kg b.w for 22 days) are associated with spaces separating the cortical tissue, attributed to the cellular degeneration and interstitial edema, mesangial cell proliferative glomerulonephritis in rat, and dilation of Bowman's spaces.

Our results indicated that in cadmium-induced nephrotoxicity pretreatment of AT ( $20 \mathrm{mg} / \mathrm{kg} / \mathrm{day}$ ) significantly improved concentrations of SOD, GSH and GPx in rat kidney and significantly decreased MDA, BUN, and Creatinine contents. The results of this study confirm previous studies, suggesting the antioxidant effect of AT. (Ghelani et al., 2019; Ozbek et al., 2009) Additionally, our findings suggest that the administration of AT might reduce cadmium-induced tissue damage. Similar to our findings ElMoselhy et al.(El-Moselhy and El-Sheikh, 2014) showed AT intake (10 mg/kg for 10 days) produced a renal protective effect against doxorubicin $(15 \mathrm{mg} / \mathrm{kg}$ for 5 days) induced nephrotoxicity.

\section{Conclusion}

This study indicated that varying doses of Cdcl2 caused oxidative stress and accounted for decreasing enzymatic activity in neutralizing free radicals and histological changes. Our results highlighted AT might protect rats against $\mathrm{CdCl}$ 2-induced oxidative stress. Workers must be informed about the potential health effects related to $\mathrm{Cd}$ exposure. We proposed that AT might be clinically relevant to $\mathrm{CdCl}$-induced renal disorders due to its potential therapeutic use in industrial workers.

\section{Declarations}

Ethical approval: The methodology for this study was approved by the Research Ethics committee of the Semnan University of Medical (Ethics approval number: (IR.SEMUMS.REC.1395.177).

Consent to participate: Animal studies: Animal experiments were performed in accordance with guidelines for animal acts established and proposed by the institutional Ethical Review Board of Semnan University of Medical Sciences.

Consent to Publish: Not applicable

Authors Contributions: $A D, E K, Z G$ contributed to conception, design, drafting and revising of the study. $A G, A R B, S Y$ conducted experiments, AD, EK, ZG, AG, ARB performed data analyses and interpretations. $A D, E K, Z G$ contributed to writing and revising manuscript. $A D$ supervised the study and final approval of the version to be published. The authors declare that all data were generated in-house and that no paper mill was used.

Funding: The research leading to these results received funding from Semnan University of Medical Sciences under Grant (Ref: A-10-361-1). 
Competing Interests: The authors declared no potential discord of interest with respect to the research, authorship, and publication of this article.

Availability of data and materials: supplemental original source data files

\section{Acknowledgments}

The authors would like to appreciate Semnan University of Medical Sciences for their financial support of this research project. The research leading to these results received funding from Semnan University of Medical Sciences under Grant (Ref: A-10-361-1).

\section{References}

1. Adi PJ, Burra SP, Vataparti AR, Matcha B (2016) Calcium, zinc and vitamin E ameliorate cadmiuminduced renal oxidative damage in albino Wistar rats. Toxicol Reports 3:591-597. https://doi.org/10.1016/j.toxrep.2016.07.005

2. Andjelkovic M, Buha Djordjevic A, Antonijevic E, Antonijevic B, Stanic M, Kotur-Stevuljevic J, Spasojevic-Kalimanovska V, Jovanovic M, Boricic N, Wallace D, Bulat Z (2019) Toxic Effect of Acute Cadmium and Lead Exposure in Rat Blood, Liver, and Kidney. Int J Environ Res Public Health 16:274. https://doi.org/10.3390/ijerph16020274

3. Bernhoft RA (2013) Cadmium Toxicity and Treatment. Sci. World J. 2013, 1-7. https://doi.org/10.1155/2013/394652

4. Brouwers B, Pruniau VPEG, Cauwelier EJG, Schuit F, Lerut E, Ectors N, Declercq J, Creemers JWM (2013) Phlorizin Pretreatment Reduces Acute Renal Toxicity in a Mouse Model for Diabetic Nephropathy*. J Biol Chem 288:27200-27207. https://doi.org/10.1074/jbc.M113.469486

5. El-Moselhy MA, El-Sheikh AAK (2014) Protective mechanisms of atorvastatin against doxorubicininduced hepato-renal toxicity. Biomed Pharmacother 68:101-110.

https://doi.org/10.1016/j.biopha.2013.09.001

6. El-Sokkary GH, Nafady AA, Shabash EH (2010) Melatonin administration ameliorates cadmiuminduced oxidative stress and morphological changes in the liver of rat. Ecotoxicol Environ Saf 73:456-463. https://doi.org/10.1016/j.ecoenv.2009.09.014

7. Erboga M, Kanter M, Aktas C, Sener U, Fidanol Erboga Z, Bozdemir Donmez Y, Gurel A (2016) Thymoquinone Ameliorates Cadmium-Induced Nephrotoxicity, Apoptosis, and Oxidative Stress in Rats is Based on its Anti-Apoptotic and Anti-Oxidant Properties. Biol Trace Elem Res 170:165-172. https://doi.org/10.1007/s12011-015-0453-x

8. Evcimen M, Aslan R, Gulay MS (2020) Protective effects of polydatin and grape seed extract in rats exposed to cadmium. Drug Chem Toxicol 43:225-233.

https://doi.org/10.1080/01480545.2018.1480629

9. Fuentes-Orozco C, Garcia-Salazar SJ, Gómez-Navarro B, González-Espinoza E, Zepeda-González A, Ramírez-Robles JN, Castañeda-Espinoza R, Yáñez-Sánchez I, Gálvez-Gastelum FJ, Cervantes-Guevara 
G, Cervantes-Cardona GA, Contreras-Hernández GI, Pérez-Landeros JE, García-Martinez D, GonzálezOjeda A (2018) Anti-Inflammatory Effect of Atorvastatin on the Kidney Graft of Living Donor Transplants. Ann Transplant 23:442-449. https://doi.org/10.12659/AOT.908521

10. Gabr SA, Alghadir AH, Ghoniem GA (2019) Biological activities of ginger against cadmium-induced renal toxicity. Saudi J Biol Sci 26:382-389. https://doi.org/10.1016/j.sjbs.2017.08.008

11. Garjani A, Rezazadeh H, Andalib S, Ziaee M, Doustar Y, Soraya H, Garjani M, Khorrami A, Asadpoor M, Maleki-Dizaji N (2012) Ambivalent effects of atorvastatin on angiogenesis, epidermal cell proliferation and tumorgenesis in animal models. Iran Biomed J 16:59-67. https://doi.org/10.6091/ibj.1017.2012

12. Ghelani H, Razmovski-Naumovski V, Inampudi V, Chang D, Nammi S (2019) Atorvastatin Improves Hepatic Lipid Metabolism and Protects Renal Damage in Adenine-Induced Chronic Kidney Disease in Sprague-Dawley Rats. Biomed Res. Int. 2019, 1-10. https://doi.org/10.1155/2019/8714363

13. Golbaghi A, Fouladi Dehagi B, Ahmadizadeh M (2019) Combined effect of cadmium and noise on rat's kidney. J Ren Inj Prev 8:230-234. https://doi.org/10.15171/jrip.2019.43

14. Goodarzi Z, Karami E, Ahmadizadeh M (2016) Simvastatin attenuates chromium-induced nephrotoxicity in rats. J Nephropathol 6:5-9. https://doi.org/10.15171/jnp.2017.02

15. Goodarzi Z, Karami E, Yousefi S, Dehdashti A, Bandegi AR, Ghanbari A (2020) Hepatoprotective effect of atorvastatin on Cadmium chloride induced hepatotoxicity in rats. Life Sci 254:117770. https://doi.org/10.1016/j.lfs.2020.117770

16. Hormozi M, Mirzaei R, Nakhaee A, Izadi S, Dehghan Haghighi J (2018) The biochemical effects of occupational exposure to lead and cadmium on markers of oxidative stress and antioxidant enzymes activity in the blood of glazers in tile industry. Toxicol Ind Health 34:459-467. https://doi.org/10.1177/0748233718769526

17. Kim KS, Lim H-J, Lim JS, Son JY, Lee J, Lee BM, Chang S-C, Kim HS (2018) Curcumin ameliorates cadmium-induced nephrotoxicity in Sprague-Dawley rats. Food Chem Toxicol 114:34-40. https://doi.org/10.1016/j.fct.2018.02.007

18. Mehany HA, Abo-youssef AM, Ahmed LA, Arafa E-SA, El-Latif A, H.A (2013) Protective effect of vitamin $E$ and atorvastatin against potassium dichromate-induced nephrotoxicity in rats. Beni-Suef Univ J Basic Appl Sci 2:96-102. https://doi.org/10.1016/j.bjbas.2013.02.002

19. Mehrzadi S, Kamrava SK, Dormanesh B, Motevalian M, Hosseinzadeh A, Hosseini Tabatabaei SMT, Ghaznavi H (2016) Melatonin synergistically enhances protective effect of atorvastatin against gentamicin-induced nephrotoxicity in rat kidney. Can J Physiol Pharmacol 94:265-271. https://doi.org/10.1139/cjpp-2015-0277

20. Messaoudi I, El Heni J, Hammouda F, Saïd K, Kerkeni A (2009) Protective Effects of Selenium, Zinc, or Their Combination on Cadmium-Induced Oxidative Stress in Rat Kidney. Biol Trace Elem Res 130:152-161. https://doi.org/10.1007/s12011-009-8324-y

21. Mezynska M, Brzóska MM (2018) Environmental exposure to cadmium-a risk for health of the general population in industrialized countries and preventive strategies. Environ Sci Pollut Res 
25:3211-3232. https://doi.org/10.1007/s11356-017-0827-z

22. Mohammed ET, Hashem KS (2019) Ameliorative Effect of Lipoic Acid on Cadmium Induced Hepatotoxicity and Nephrotoxicity in Rats. J Appl Sci 19:637-646.

https://doi.org/10.3923/jas.2019.637.646

23. Moitra S, Brashier BB, Sahu S (2014) Occupational cadmium exposure-associated oxidative stress and erythrocyte fragility among jewelry workers in India. Am J Ind Med 57:1064-1072. https://doi.org/10.1002/ajim.22336

24. Nasri H, Hasanpour Z, Nematbakhsh M, Ahmadi A, Rafieian-Kopaei M (2016) The effect of the various doses of atorvastatin on renal tubular cells; an experimental study. J Nephropathol 5:111115. https://doi.org/10.15171/jnp.2016.20

25. Ozbek E, Cekmen M, Ilbey YO, Simsek A, Polat EC, Somay A (2009) Atorvastatin Prevents GentamicinInduced Renal Damage in Rats through the Inhibition of p38-MAPK and NF-kB Pathways. Ren Fail 31:382-392. https://doi.org/10.1080/08860220902835863

26. Pal S, Sarkar A, Pal PB, Sil PC (2015) Protective effect of arjunolic acid against atorvastatin induced hepatic and renal pathophysiology via MAPK, mitochondria and ER dependent pathways. Biochimie 112:20-34. https://doi.org/10.1016/j.biochi.2015.02.016

27. Patra RC, Rautray AK, Swarup D (2011) Oxidative Stress in Lead and Cadmium Toxicity and Its Amelioration. Vet. Med. Int. 2011, 1-9. https://doi.org/10.4061/2011/457327

28. Pirmoradi Z, Yadegari M, Moradi A, Khojasteh F, Mehrjerdi FZ (2019) Effect of berberine chloride on caspase-3 dependent apoptosis and antioxidant capacity in the hippocampus of the chronic cerebral hypoperfusion rat model. Iran J Basic Med Sci. https://doi.org/10.22038/ijbms.2018.31225.7534

29. Rana MN, Tangpong J, Rahman MM (2018) Toxicodynamics of Lead, Cadmium, Mercury and Arsenic- induced kidney toxicity and treatment strategy: A mini review. Toxicol Reports 5:704-713. https://doi.org/10.1016/j.toxrep.2018.05.012

30. Renugadevi J, Prabu SM (2009) Naringenin protects against cadmium-induced oxidative renal dysfunction in rats. Toxicology 256:128-134. https://doi.org/10.1016/j.tox.2008.11.012

31. Satarug S, Haswell-Elkins MR, Moore MR (2000) Safe levels of cadmium intake to prevent renal toxicity in human subjects. Br J Nutr 84:791-802. https://doi.org/10.1017/S0007114500002403

32. Sheikh N (2016) Lipid Peroxidation and Antioxidant Status in Patients with Medullary Thyroid Carcinoma: A Case-Control Study. J Clin DIAGNOSTIC Res. https://doi.org/10.7860/JCDR/2016/17854.7202

33. Şişman AR, Bülbül M, Çoker C, Önvural B (2003) Cadmium exposure in tobacco workers: possible renal effects. J Trace Elem Med Biol 17:51-55. https://doi.org/10.1016/S0946-672X(03)80046-9

34. Sun Y-M, Tian Y, Li X, Liu Y-Y, Wang L-F, Li J, Li Z-Q, Pan W (2009) Effect of atorvastatin on expression of IL-10 and TNF-a mRNA in myocardial ischemia-reperfusion injury in rats. Biochem Biophys Res Commun 382:336-340. https://doi.org/10.1016/j.bbrc.2009.03.019

35. Talebpour Amiri F, Hamzeh M, Naeimi RA, Ghasemi A, Hosseinimehr SJ (2018) Radioprotective effect of atorvastatin against ionizing radiation-induced nephrotoxicity in mice. Int J Radiat Biol 94:106- 
113. https://doi.org/10.1080/09553002.2018.1420926

36. Verdi LG, Brighente IMC, Pizzolatti MG (2005) Gênero Baccharis (Asteraceae): aspectos químicos, econômicos e biológicos. Quim Nova 28:85-94. https://doi.org/10.1590/S010040422005000100017

37. Wallin M, Sallsten G, Lundh T, Barregard L (2014) Low-level cadmium exposure and effects on kidney function. Occup Environ Med 71:848-854. https://doi.org/10.1136/oemed-2014-102279

38. Wang X, Zhang T, Hu L, Sun S-Q, Zhang W, Sun Z, Shen L, He B (2017) Comparison of Effects of Different Statins on Contrast-Induced Acute Kidney Injury in Rats: Histopathological and Biochemical Findings. Oxid. Med. Cell. Longev. 2017, 6282486. https://doi.org/10.1155/2017/6282486

39. Wu K, Lei W, Tian J, Li H (2014) Atorvastatin treatment attenuates renal injury in an experimental model of ischemia-reperfusion in rats. BMC Nephrol 15:14. https://doi.org/10.1186/1471-2369-1514

40. Xiao P, Jia X-D, Zhong W-J, Jin X-P, Nordberg G (2002) Restorative effects of zinc and selenium on cadmium-induced kidney oxidative damage in rats. Biomed Environ Sci 15:67-74

41. Yan L, Jiaqiong L, Yue G, Xiaoyong L, Xuexian T, Ming L, Yinglan L, Xinxue L, Zena H (2020) Atorvastatin protects against contrast-induced acute kidney injury via upregulation of endogenous hydrogen sulfide. Ren Fail 42:270-281. https://doi.org/10.1080/0886022X.2020.1740098

42. Yang H, Shu Y (2015) Cadmium Transporters in the Kidney and Cadmium-Induced Nephrotoxicity. Int J Mol Sci 16:1484-1494. https://doi.org/10.3390/ijms16011484

\section{Figures}

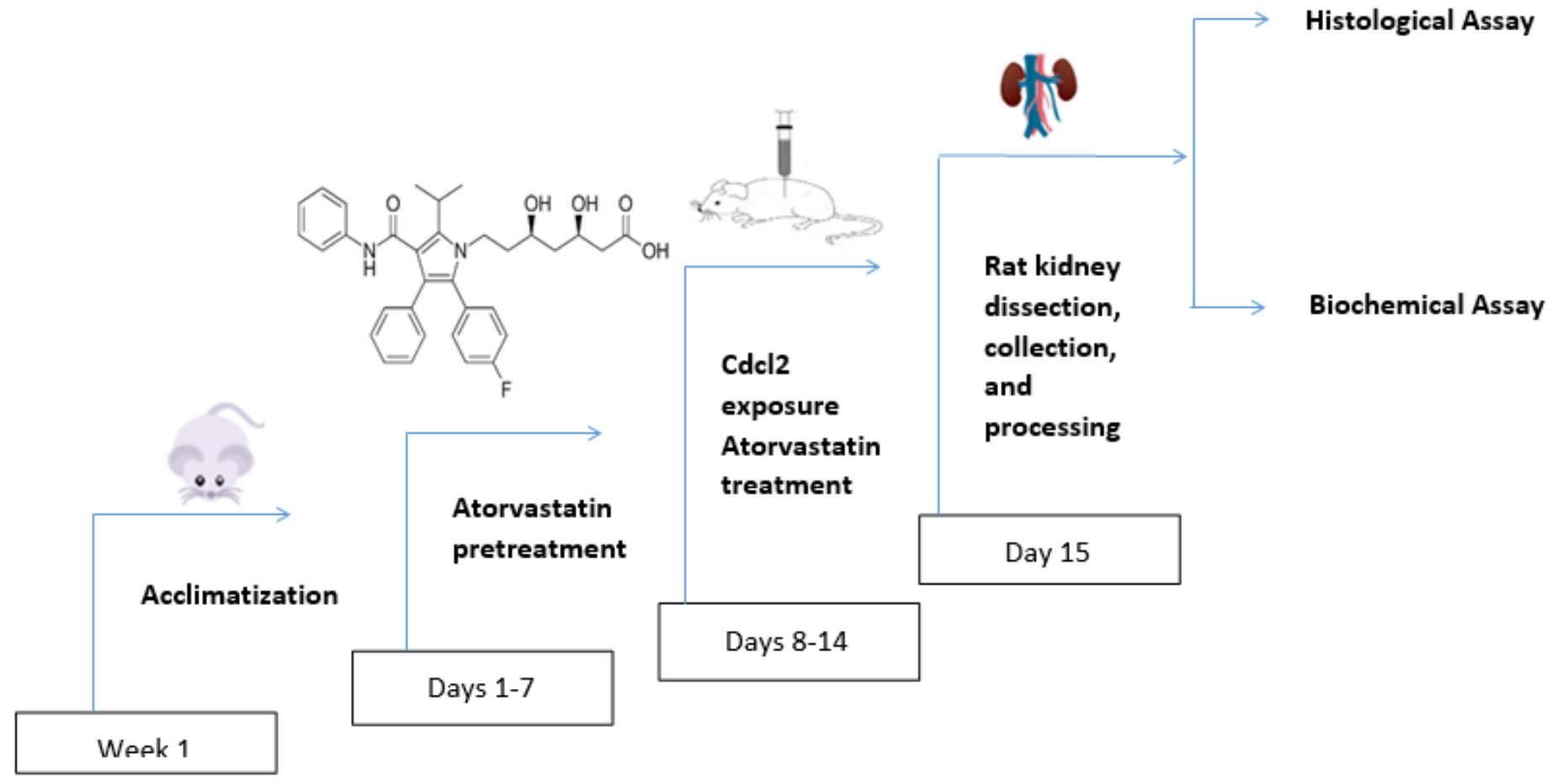


Figure 1

The time schedule for experimental rat treatments

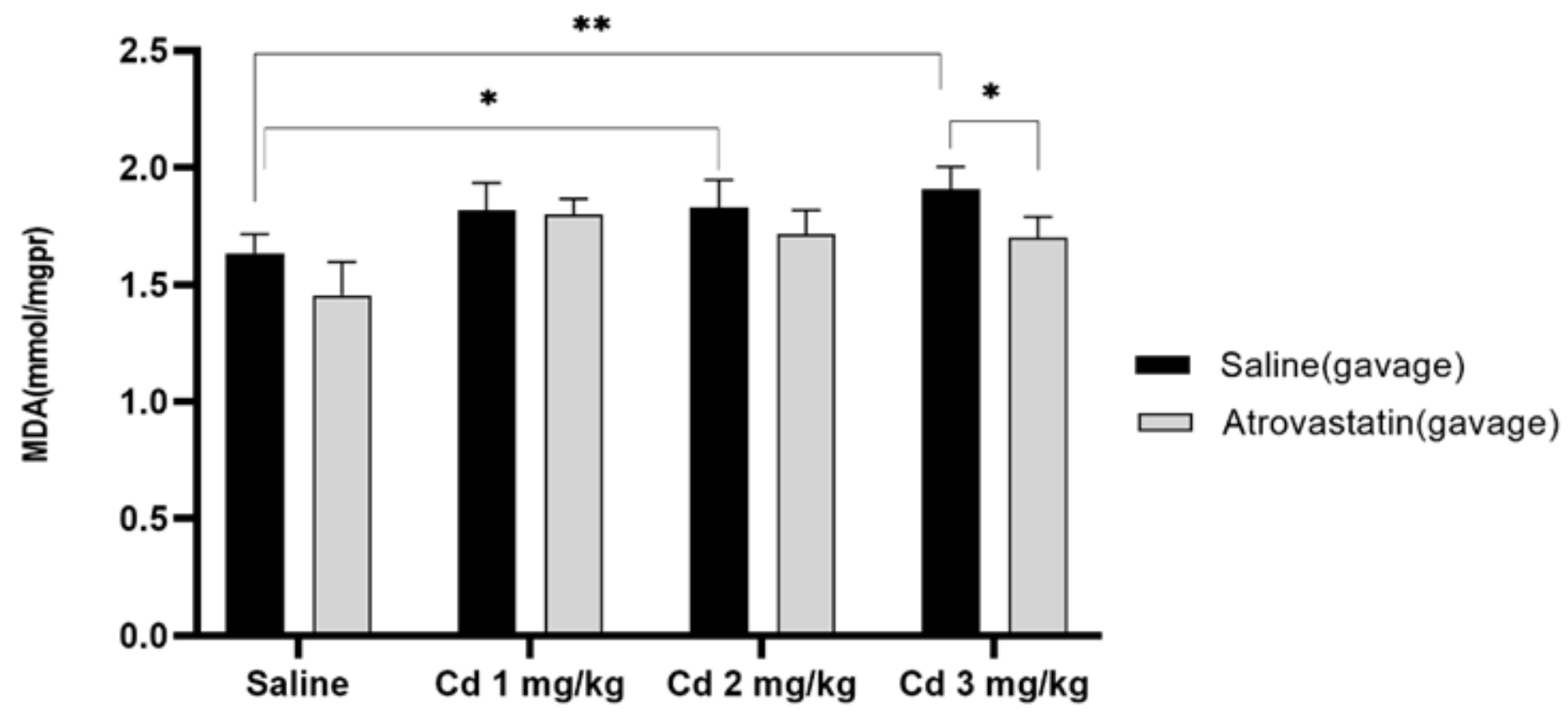

Figure 2

Effects of AT on MDA levels in kidney tissues of rats treated with Cdcl2 at doses of 1,2, and $3 \mathrm{mg} / \mathrm{kg}$. Administration of Cdcl2 ( 2 and $3 \mathrm{mg} / \mathrm{kg}$ ) significantly increased levels of MDA in serum compared to the rats received saline. Pretreatment with AT decreased the effect of Cdcl2 $(3 \mathrm{mg} / \mathrm{kg})$. Presented figures are mean \pm S.E.M $(n=7) 0.05999$. ${ }^{*} P<0.05,{ }^{*} P<<0.01$. 

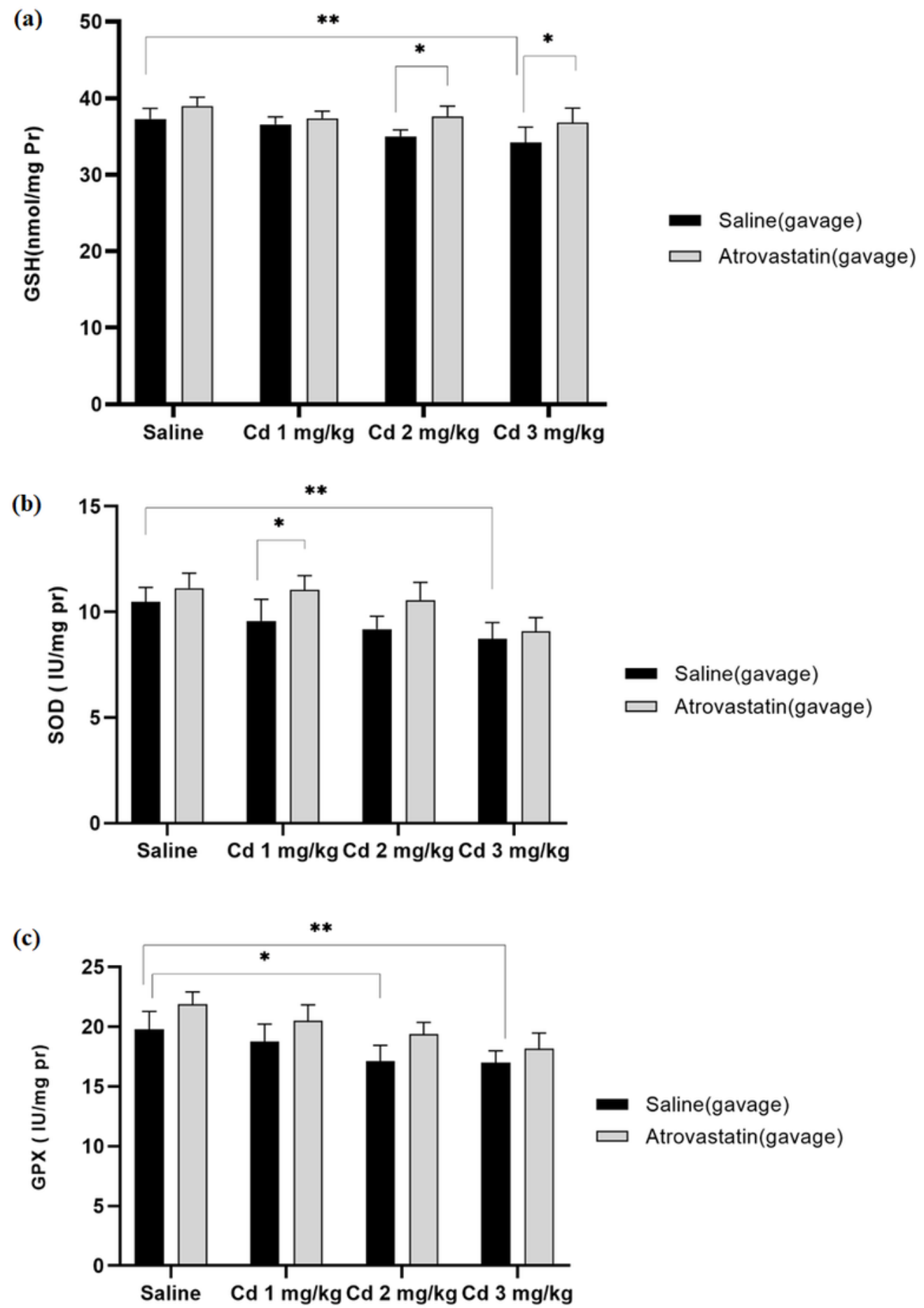

Figure 3

a.Effects of AT on GSH levels in kidney of rats received Cdcl2 (1, 2 and $3 \mathrm{mg} / \mathrm{kg})$. Administration of Cdcl2 ( $3 \mathrm{mg} / \mathrm{kg}$ ) significantly lowered the content of GSH. Pretreatment of AT significantly suppressed the Cdcl2-induced effects of 2 and $3 \mathrm{mg} / \mathrm{kg}$ doses. Values are mean \pm S.E.M $(\mathrm{n}=7) 0.7959$. ${ }^{*} \mathrm{P}<0.05$, ${ }^{\star \star} \mathrm{P}$ $<0.01$. b. Effects of AT on SOD activity in the kidney tissues of rats received Cdcl2 (1, 2, and $3 \mathrm{mg} / \mathrm{kg})$. Cdcl2 (3 mg/kg) significantly decreased the content of SOD compared to the saline-treated rats. AT 
pretreatment improved SOD at the level of control group and significantly suppressed the effect of Cdcl2 $(1 \mathrm{mg} / \mathrm{kg})$. Results are mean \pm S.E.M $(n=7) 0.4352$. ${ }^{\star} P<0.05$, ${ }^{\star *} P<0.01$. c. Effects of AT on GPx activity in renal tissues of rats received Cdcl 2 with doses of 1,2 , and $3 \mathrm{mg} / \mathrm{kg}$. Data showed no significant difference of GPx levels between rats pretreated with AT and the rats received the various doses of $\mathrm{Cdcl} 2$. Results are mean \pm S.E.M $(n=7) 0.7233$. ${ }^{*} P=0.0078, * P=0.0138$.

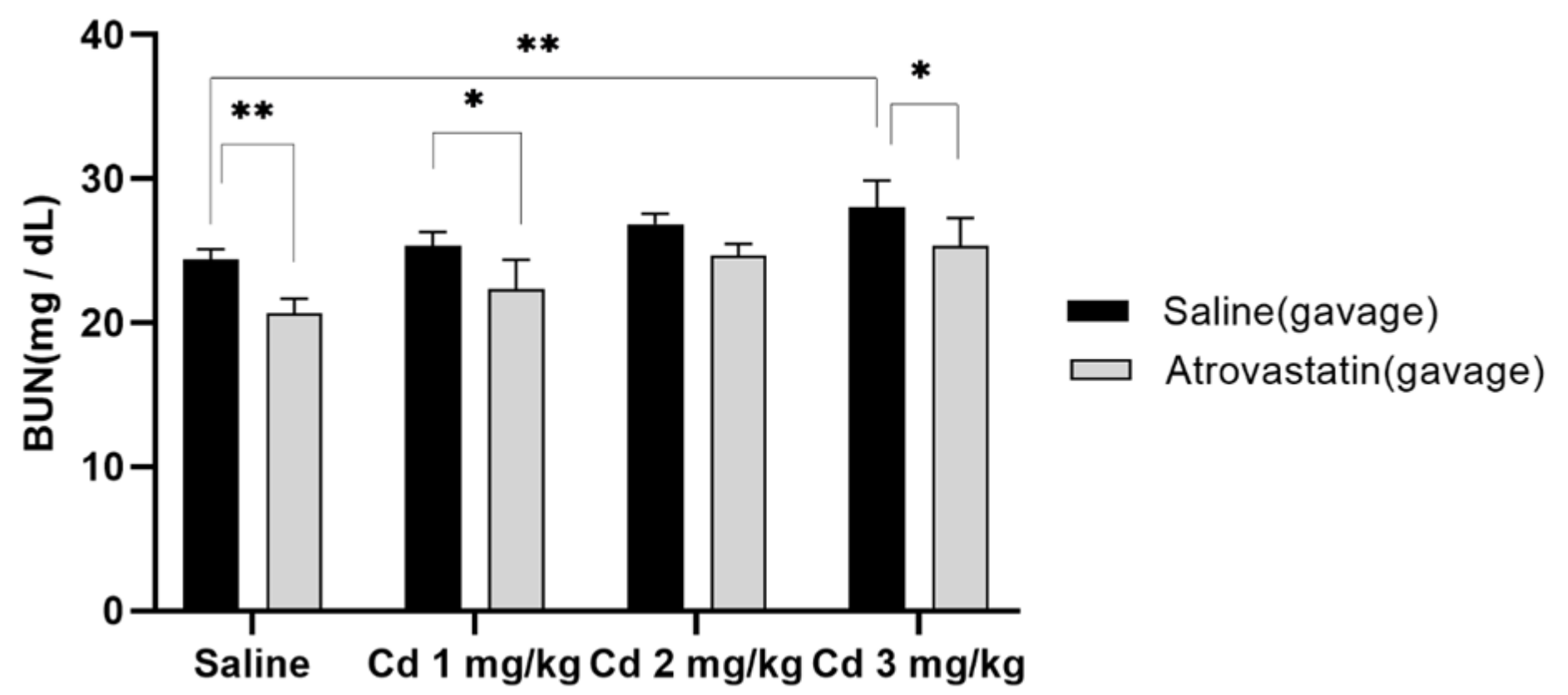

Figure 4

Effects of AT on BUN concentrations in the rats exposed to Cdcl2 with doses 1,2, and $3 \mathrm{mg} / \mathrm{kg}$. Administration of $\mathrm{Cdcl} 2(3 \mathrm{mg} / \mathrm{kg})$ significantly increased the level of BUN. AT pretreatment significantly decreased BUN compared to saline and Cdcl2-treated rats (1 and $3 \mathrm{mg} / \mathrm{kg}$ ). Figures are mean \pm S.E.M $(n=7)(0.8043)$. Saline and $A T * * * P=.0009, C d 3$ and saline ${ }^{\star * P} P=.0015, C d 1$ and $A T+C d 1 * P=.0123, C d 3$ and $A T+C d 3 * P=.0378$. 


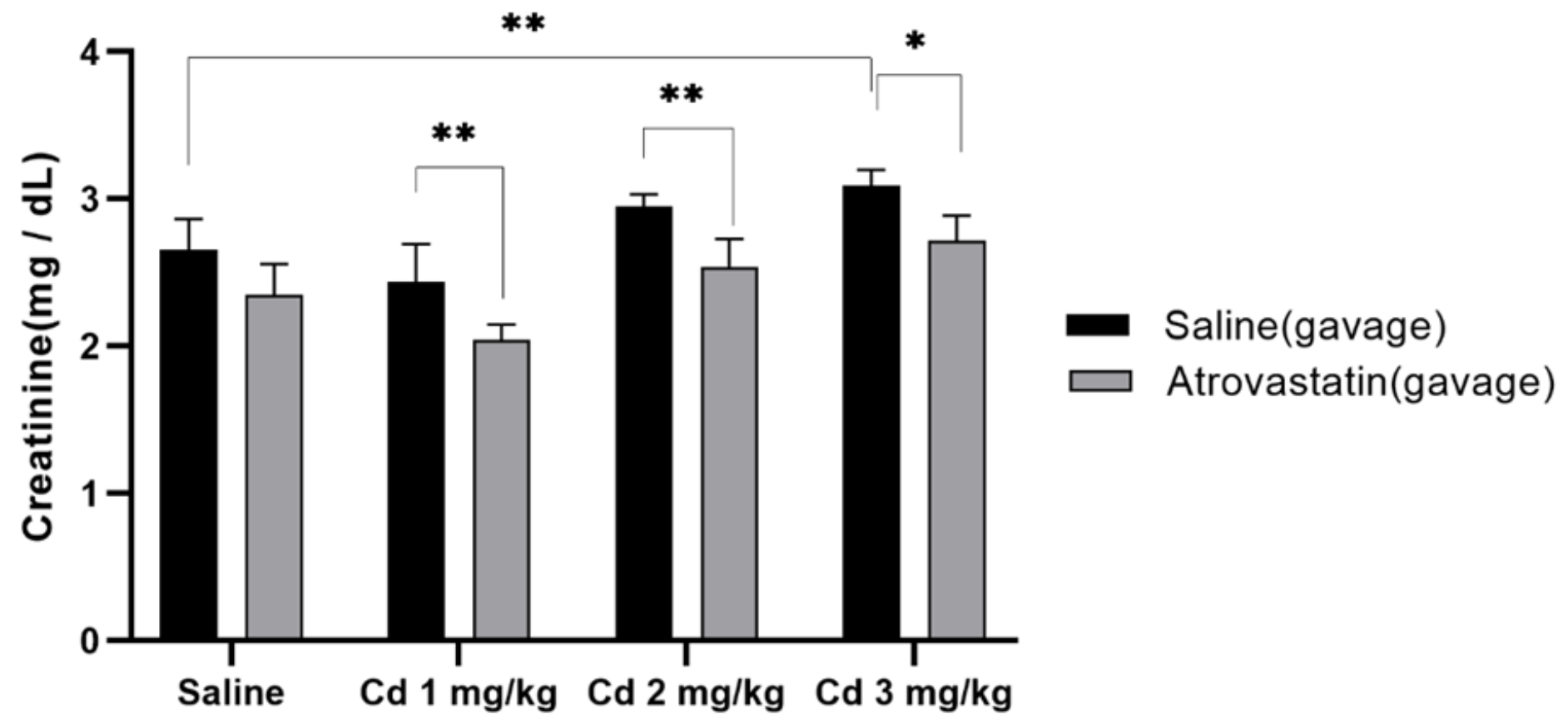

Figure 5

Effects of AT on creatinine in rat kidney tissues exposed to Cdcl2. Administration of Cdcl2 $(3 \mathrm{mg} / \mathrm{kg})$, induced significant increase in creatinine level compared to the rats treated with saline and AT pretreatment significantly decreased creatinine and the effect of Cdcl $2(1,2$ and $3 \mathrm{mg} / \mathrm{kg})$. Results are presented as mean \pm S.E.M $(n=7) 0.1018$. ${ }^{*} P<0.02, * * P<0.01$. 


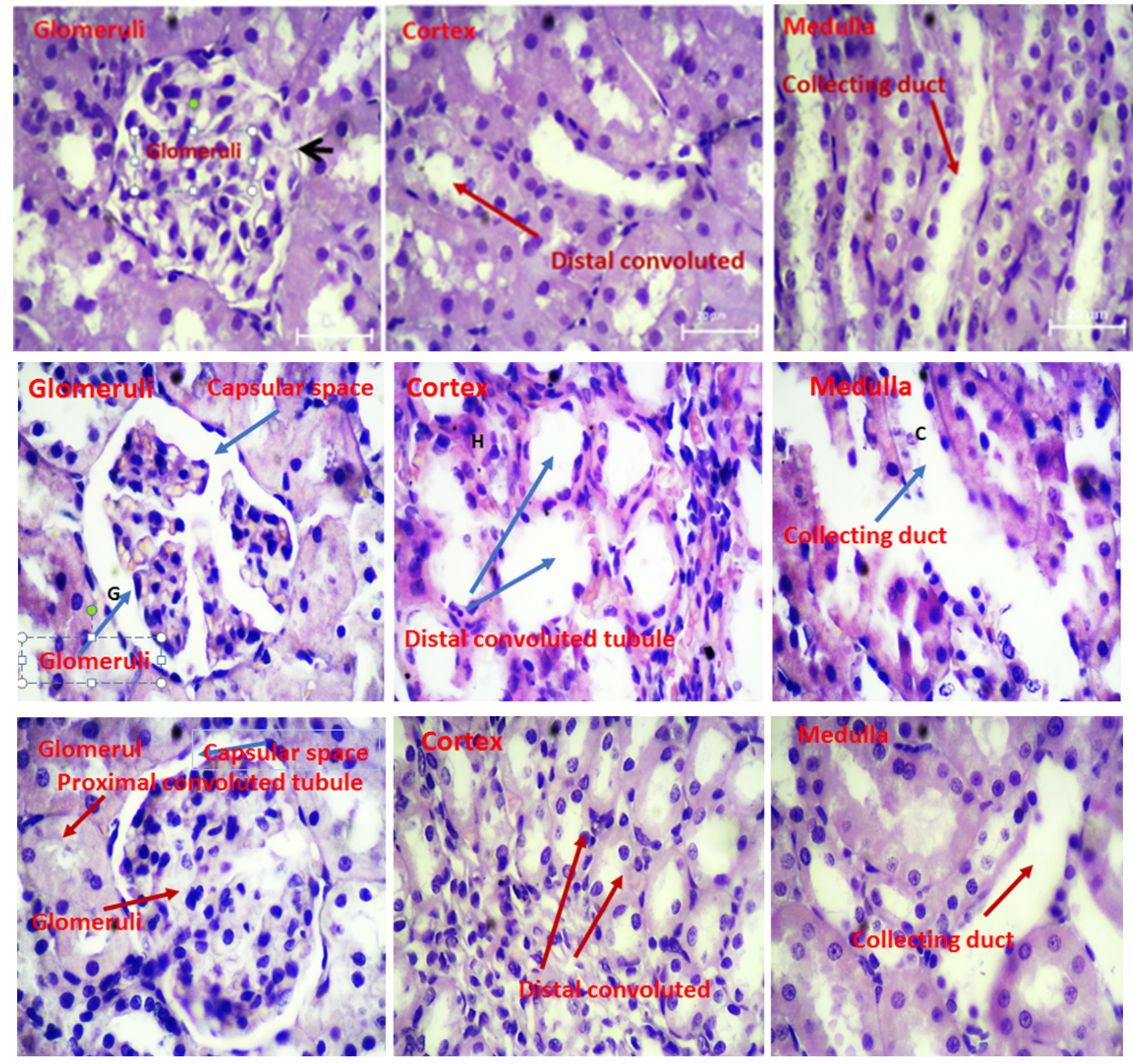

\section{Figure 6}

a. Light microscopy of rat renal tissue of the control group under normal saline treatment illustrating the healthy architecture of Bowman's capsule (black arrow), glomeruli, distal tubules, and collector duct. b. Light microscopy of rat kidney received $\mathrm{CdCl} 2$ displaying renal damages: degeneration of glomeruli $(\mathrm{G})$, hemorrhage $(\mathrm{H})$, deposited epithelial cells in collector duct (C). c. Light microscopy of rat kidney structure following treatment of AT $(20 \mathrm{mg} / \mathrm{kg})$ and $30 \mathrm{~min}$ before administration of $\mathrm{CdCl} 2$. AT protective effect on injury in the kidney tissue, exhibiting normal kidney tissue structure with glomeruli, renal distal convoluted, and collecting duct. 


\section{Supplementary Files}

This is a list of supplementary files associated with this preprint. Click to download.

- SupportingInformationexperimentaldatatest.pdf

- SupportinginformationFigures.pdf 